\title{
Productivity and food security effects of using of certified seed potato: the case of Kenya's potato farmers
}

\author{
Julius Juma Okello ${ }^{* *}$, Yuan Zhou ${ }^{2}$, Norman Kwikiriza', Sylvester Ogutu ${ }^{3}$, lan Barker², \\ Elmar Schulte-Geldermann ${ }^{1}$, Elly Atieno ${ }^{1}$ and Justin Taj Ahmed ${ }^{4}$
}

\begin{abstract}
Background: Potato is a major food crop in the tropical regions of Africa. However, potato yields continue to remain very low in these regions mainly due to use of poor quality seed. The recent development of rapid seed multiplication technique has helped to shorten the duration of certified seed potato (CSP) production and increase the supply of seed. This study assessed the effect of using CSP on yield, input use, and food security among smallholder farmers. It focused on potato growers in central highlands of Kenya, who were in close proximity to a private seed multiplier that uses these new techniques. The study used the propensity score matching technique and data collected from 408 smallholder farmers through personal interviews. The farmers were stratified by use of CSP.
\end{abstract}

Results: The study found positive effect of using certified seed on both yield and food security. There was also a slight increase in input usage, apparently due to pursuit by farmers to optimize the gains from CSP.

Conclusion: The study concludes that using CSP has positive effect on smallholder farm households.

Keywords: Smallholder farmers, Certified seed potato, Use and effect, Propensity score matching, Kenya

\section{Background}

Potato (Solanum tuberosum) is a major crop in tropical highland regions of Sub-Saharan Africa, where it is grown both as a horticultural crop (due to its high value) and as a food security crop. Globally, it ranks fourth after maize, rice, and wheat [1]. In Kenya, it is the second most important food crop after maize [2, 3]. It plays an important role as a food staple among producing households and also contributes to poverty alleviation through income generation [4]. An estimated 800,000 farmers grow potato in Kenya [5], while over 2.5 million Kenyans are employed along the potato value chain, either directly or indirectly [6]. As in the rest of the tropical highlands of Africa, potato production in Kenya is dominated by smallholder farmers.

\footnotetext{
${ }^{*}$ Correspondence: j.okello@cgiar.org

1 International Potato Center, Sub Sahara Africa Regional Office, Nairobi, Kenya

Full list of author information is available at the end of the article
}

Despite its importance, potato production continues to be undermined by lack of certified seed potato (CSP). The lack of CSP in turn leads to recycling of seed, causing the buildup of pests and diseases among smallholder farms $[4,6]$. Consequently, the average potato yields in tropical highlands of Africa fluctuate between 8 and 10 tons per hectare, compared to 40 tons per hectare obtained in countries in North America and Western Europe [2, 7]. Low yields, on the other hand, result in low incomes and contribute to food insecurity and poverty among small farm households, and confine them in subsistence agriculture $[8,9]$.

Until recently, seed production in Kenya was largely in the hands of the public sector. Under this system, the government was responsible for production of seed. However, lack of capacity to increase production in tandem with an increase in demand led to shortage in supply. Further, production of seed was limited to two areas (i.e., Tigoni and Molo) - both of which are quite far from most farmers in the Mount Kenya region. The bulky 
nature of the seed further made it very costly to transport seed to the producing areas. The low supply and high cost of transportation lead to increase in price, making seed unaffordable to farmers.

Recent joint efforts by some of the public and private sectors to increase the supply of seed hence reverse the low yields, led to the development of a rapid seed multiplication technique, commonly known as " $3 G$ " technique. The technique produces CSP in three generations of field multiplication, as opposed to the conventional 5-7 generations [10]. The seed produced is free from most potato pests and diseases. Kenya, Tanzania, Ethiopia, Malawi, and Uganda are among countries that have adopted this technique. To improve access to CSP by smallholder farmers, a private sector partner establishes a seed multiplication farm within the potato producing areas. In Kenya, for instance, Kisima Farm Ltd (KFL), the private sector partner, established a farm in Nanyuki, close to leading producing potato areas of Meru and Nyandarua counties. The farm sells its CSP to smallholder farmers within the radius of about $30 \mathrm{~km}$ and has retail outlets in other locations that give smallholder farmers around such outlets easier access to CSP. It multiplies and sells four CSP potato varieties, namely Kenya Mpya, Sherekea, Asante, and Tigoni. The growing of CSP is usually promoted with the goal of reducing yield gap and improving the welfare of farm households by increasing yields, food supply and hence food security. Improvements in household food security status follow from the fact that potato is a staple among producers [4].

This study uses data collected from a random sample of 408 potato farmers in central highland region of Kenya to assess the effect of using CSP on small farm households. It specifically focused on yield, household food security, and input usage as the outcome variables. The rest of this paper is organized as follows: "Methods" section presents the conceptual as well as the analytical framework and the hypotheses tested. "Results and discussion" section presents the results, while "Summary conclusions and implications" section concludes and provides some policy implications of the findings.

\section{Methods}

\section{Estimation of the effects of using certified seed potato on productivity and food security}

An individual's or household's decision to adopt or use a new technology is affected by the net benefits of doing so $[9,11]$. Following [12] and [9], this study modeled the effect of using CSP on farm households as a linear function of explanatory variables $\left(X_{i}\right)$ and dummy variable $\left(R_{\mathrm{i}}\right)$ representing the use of CSP. The linear regression model for assessing the effect of CSP can be specified as;

$$
Y=\beta X_{i}+A R_{i}+\mu_{i}
$$

where $Y$ is the mean outcome variable (yield, input use, and household food insecurity) being affected by the use of CSP, $R_{i}=1$ if a farmer planted CSP, 0 otherwise, and $\mu_{i}$ the error term.

Whether farmers use CSP or not is dependent on the characteristics of the farmers and farms, as well as asset endowments, among other factors. Assuming a risk-neu$\mathrm{tral}^{1}$ farmer, the index function to estimate adoption of CSP is expressed as:

$$
R_{i}^{*}=\gamma X_{i}+e_{i}
$$

where $R_{i}^{*}$ ia latent variable denoting the difference between utility from using CSP $U_{i K}$ and the utility from using other kinds of seed $\left(U_{i N}\right)$. The farmer will thus use CSP if:

$$
R_{i}^{*}=U_{i K}-U_{i N}>0 .
$$

The term $\gamma X_{i}$ in Eq. 2 provides an estimate of the difference in utility from using $\operatorname{CSP}\left(U_{i K}-U_{i N}\right)$, with household and farm-level characteristics, as explanatory variables, while $e_{i}$ is an error term. Close inspection of Eqs. 1 and 2 will, however, show that $\mathrm{X}$ and $\mathrm{Y}$ are interrelated and that there is the presence of selection bias. Selection bias occurs if some unobservable factors influence both the error terms $(\mu)$ and $(e)$ of the outcome equation and the technology choice equation, respectively, thus resulting in correlation of the two error terms. Hence, estimating Eq. 1 using the ordinary least squares regression technique leads to biased estimates.

To control for the self-selection bias, this study used propensity score matching technique. This technique matches the two groups (i.e., users and non-users of CSP), so as to create a plausible counterfactual which will then address the problem of selection bias. Specifically, it matches a treated individual (i.e., the user) with a control individual (i.e., the non-user) that is similar in all observable characteristics except for the treatment, and computes the difference in outcome variable for the two matched individuals. That difference is the effect of treatment (i.e., the use of CSP), measured in terms of average treatment effect on the treated individuals.

The estimation procedure in PSM proceeds as follows: First, propensity scores (defined as the probability of being in a treatment group given the observable characteristics) are obtained by estimating a binary logit or probit regression model. Second, the matching algorithm is selected based on the data at hand after undertaking matching quality tests. The common matching algorithms are the nearest neighbor matching (NNM), radius

\footnotetext{
${ }^{1}$ This is a standard assumption in propensity score matching. See [12, 13] for similar treatment.
} 
matching (RM), and the kernel-based matching (KBM). A discussion of the differences among these matching strategies and how each works can be found in [12]. Third, the control (i.e., non-users of CSP) are matched with the treatment (users of CSP) using the selected matching algorithms. Fourth, tests to assess whether the assumption of common support is satisfied are conducted. Fifth, the treatment effect is estimated in the region of common support based on the matching estimator selected. Finally, sensitivity analysis is undertaken to check whether the influence of an unmeasured variable on the selection process is so strong as to undermine the treatment effect. This is achieved by using the Rosenbaum bounds (rbounds) test. A detailed discussion of the theory and implementation of the matching procedures is provided by $[12,14,15]$.

As part of the first step of implementing the PSM, we estimated a binary response model. The functional form of the empirical model estimated was:

useCSP $=f$ (lnage, gender, occupation, education, hhdsize,

Indistagric, lndistkisima, credit, Inland, lnasset,

phone, memgroup $+\varepsilon$

The model was estimated using probit regression. The descriptions of the variables in the empirical model are presented in Table 1. In the empirical model, some variables have been transformed into their natural logarithms.
These are age (lnage); distance to agriculture office (lndistagric); distance from the farmer's home to Kisima Farm (lndistkisima); size of land owned by farmer (lnland); and value of physical asset (lnasset).

The second step involved the estimation of the effect using the CSP by comparing the users and non-users on input use (fungicide, insecticide and fertilizer use, potato yield, and food insecurity). The outcome variables used are as defined in Table 1. Food insecurity was measured using the household food insecurity access prevalence (HFIAP) score.

Before comparing the CSP and non-CSP users using the propensity score matching technique, an independent sample $t$ test was done to test whether the characteristics were different between the two groups of farmers. Other variables that were used to compare the CSP users and non-CSP users are defined in Table 2.

\section{Sampling procedure and data}

The data used in this study were collected from 6 districts of the Mt Kenya region, namely Buuri, Igembe Central, Igembe South, Laikipia East, Meru Central, and Tigania East due to their proximity to the CSP source, i.e., Kisima Farm Ltd. Figure 1 shows the map of Kenya, highlighting the Mt Kenya region where the study was conducted. In each of the districts, the study focused on the villages with smallholder potato farmers who had used CSP from

Table 1 Variables used in the models and their hypothesized effects on the use of CSP

\begin{tabular}{|c|c|c|}
\hline Variables & Description of variable & Hypothesized effect \\
\hline useCSP & If the farmer plants/uses CSP ( $1=$ yes, $0=$ otherwise $)$ & Dependent variable \\
\hline age & Respondent's age measured in years & \pm \\
\hline gender & Gender of the farmer ( $1=$ male; $0=$ otherwise $)$ & \pm \\
\hline occupation & Occupation of the farmer ( $1=$ full time, $0=$ otherwise) & \\
\hline education & number of years of formal schooling & \\
\hline hhdsize & Number of household members & - \\
\hline distagric & Distance to the nearest agricultural office in walking minutes & - \\
\hline distkisima & Distance from the residence of the farmer to Kisima Farm in kilometers & - \\
\hline credit & If the farmer had access to credit ( $1=$ yes; $0=$ otherwise) & \pm \\
\hline land & Size of land (hectares) the farmer had before adopting CSP & \pm \\
\hline asset & Value of physical assets in USD & + \\
\hline phone & If the farmer owns a mobile phone ( $1=$ yes; $0=$ otherwise) & \pm \\
\hline memgrp & If the farmer is a member of a farmer organization ( $1=$ yes; $0=$ otherwise) & + \\
\hline$\varepsilon$ & The stochastic term & \\
\hline \multicolumn{3}{|c|}{$\begin{array}{l}\text { Measures of the effect of } \\
\text { use of CSP (outcome variables) }\end{array}$} \\
\hline fungicide & Value of purchased fungicide (USD/ha) & - \\
\hline insecticide & Value of purchased insecticide (USD/ha) & - \\
\hline yield & Potato yield (kg/ha) & + \\
\hline fertilizer & Value of purchased fertilizer (USD/ha) & \pm \\
\hline foodsec & HFIAP score & - \\
\hline
\end{tabular}


Table 2 Other variables used to compare CSP users and nonusers, in terms of asset ownership, potato production, and utilization

\begin{tabular}{|c|c|}
\hline Variables & Description of variable \\
\hline market & Distance to the nearest market in walking minutes \\
\hline dependency & $\begin{array}{l}\text { Ratio of household members below } 15 \text { years or above } \\
64 \text { years of age to the working age members ( } 15-64 \text { years) }\end{array}$ \\
\hline livestock_asset & Value of livestock assets (USD) \\
\hline cult_land & Total cultivated land (ha) owned by the farmer \\
\hline uncult_land & Total uncultivated land (ha) owned by the farmer \\
\hline seed_purchase & Value of seed (USD/ha) purchased by the farmer \\
\hline folier_feed & Value of foliar feed (USD/ha) purchased by the farmer \\
\hline manure & Value of manure (USD/ha) purchased by the farmer \\
\hline ware_potatosale & Amount of ware potato sold (kg/ha) \\
\hline seed_potatosale & Seed potato sales (kg/ha) \\
\hline income_potato & Income received from potato (USD/ha) \\
\hline
\end{tabular}

Kisima Farm during any of the four seasons of two years preceding the study (i.e., 2012 and 2013).

The study respondents were selected as follows: First, a list of all the villages with farmers who planted CSP from Kisima Farm was obtained and the villages that had fewer than 12 CSP purchasers were dropped. ${ }^{2}$ This procedure resulted in the selection of 21 villages in Buuri, one in Igembe Central, one in Igembe South, 2 in Laikipia East, 5 in Meru Central, and 4 in Tigania East. A total of 34 villages were therefore selected from the 6 study districts. Second, for each village, a list of all the farmers who had planted CSP from Kisima Farm Ltd during the 2 years prior to the study was drawn with the help of local administrators (village heads) and contact farmers. A second list of potato growers who used other types of seed potato was also drawn. Third, 12 respondents were selected from in each village, with the respondents drawn from of the two each list using probability proportionate to size sampling technique. That is, more farmers were sampled from the list with more names, and vice versa. This procedure resulted in the selection of 408 farmers: 167 CSP users and 241 non-users.

Eight trained enumerators collected the data from the selected farmers through personal interviews using a pretested questionnaire. The interviews ran from March to May 2014. The data were entered in SPSS and analyzed using Stata.

\section{Results and discussion}

\section{Characterization of study respondents}

Table 3 presents the demographic characteristics of users and non-users of CSP. The mean age of all the

\footnotetext{
${ }^{2}$ This was done mainly to avoid oversampling of respondents in villages with very few purchasers.
}

respondents was 49 years. On average, the respondents had eight years of education, implying that majority had only attained primary level of schooling.

Users of CSP had significantly higher average level of education than the non-users. This finding is in line with the adoption literature which suggests that education increases the likelihood of uptake of new technologies [16]. Users and non-users of CSP also differed in terms of ownership of mobile phones (an important communication tool/asset). However, the dependency ratios did not differ among the users and non-users of CSP. Results further showed that the study respondents had, on average, grown potato for 19 years and therefore had considerable amount of experience in potato farming. There was, however, no difference in potato growing experience between purchasers and non-purchasers and also between male and female farmers.

Table 4 presents the results of the analysis of the respondents' endowments with different types of assets likely to influence capacity to invest in the costly technology such the purchase of CSP. The assets are in US dollar values. The table shows that the mean value of total physical and livestock assets owned by CSP users was USD1851 and USD1783, respectively, while for non-users was USD 738 and USD 1239, respectively. Thus, CSP users were better endowed with livestock capital assets than their counterparts, as shown by the results of t-tests of differences in means. There was, however, a wide variation in the value of these assets, as indicated by the large standard deviations.

Results also show that users of CSP owned more land than their counterparts. The differences in land ownership are also statistically significant. These findings indicate that there are systematic differences between users and non-users of CSP. In other words, the users and nonusers of CSP were not drawn from the same population. Consequently, estimation of the impact/effect of CSP needs to take this difference into account-hence the use of propensity score matching technique.

\section{Effect of using CSP seed on small farm households}

Table 5 presents the results of the statistical tests of difference in the amount (in value terms) of common inputs used in potato production. It shows that users of CSP differ from their counterparts in their usage of some of the key agricultural inputs. Specifically, the results show that the amount of fertilizer and insecticides used by CSP users was significantly higher. Users of CSP spent USD 52/ha and USD4/ha more on fertilizers and insecticides, respectively, than their counterparts. There was, however, no a statistically significant difference in the amounts of fungicides applied by users and non-users of CSP. Fertilizer is often used for soil amendments and is an 


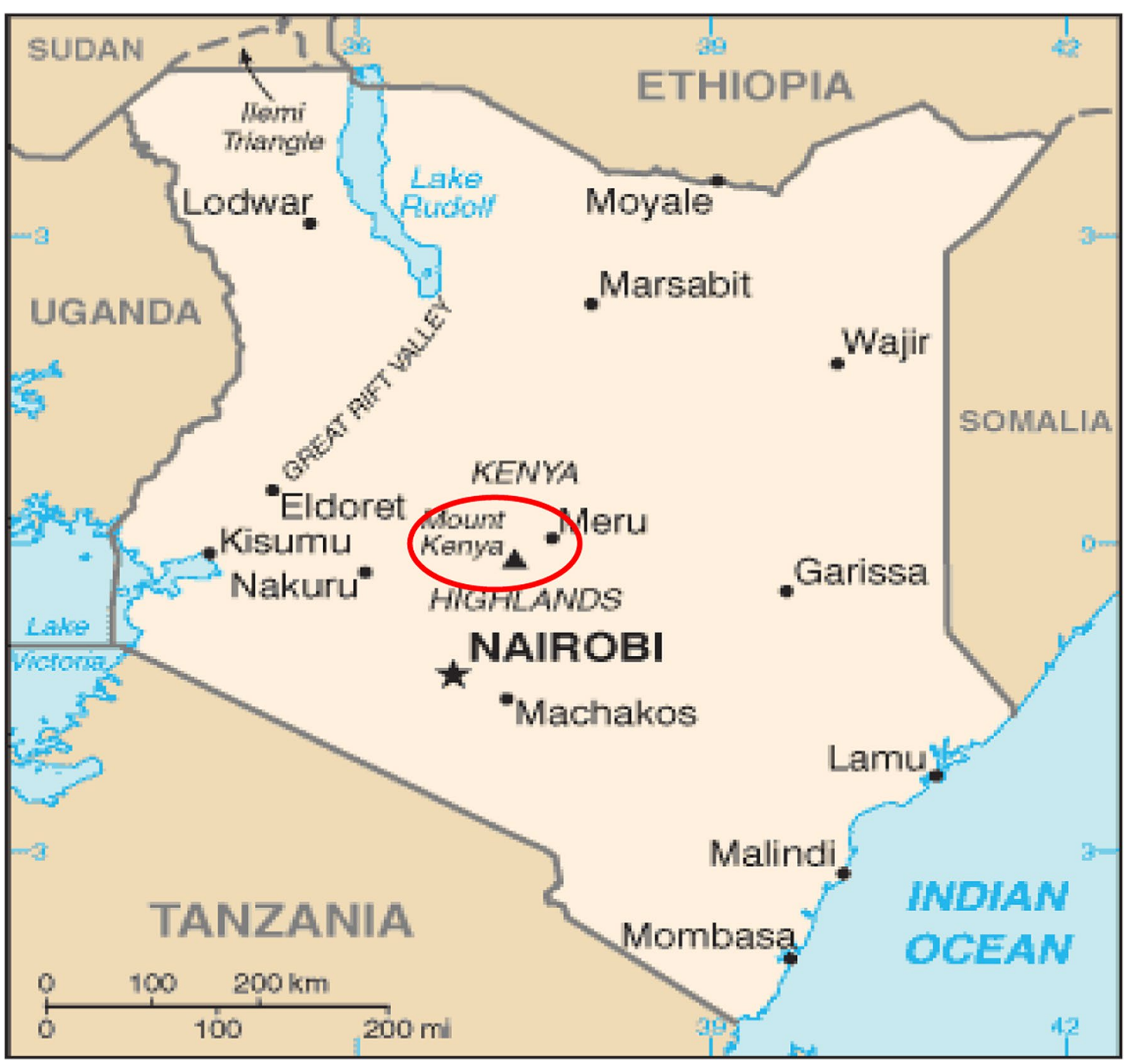

Fig. 1 Map of Kenya showing the study area

important input in increasing crop productivity in many African countries $[17,18]$. However, use of fertilizer has been associated with non-point source pollution; hence, an increase in its use can degrade the environment [19, 20]. Results show that there was no significant difference in the value of manure used by the two groups of farmers.

The use of better CSP and increased use of yieldenhancing inputs are expected to influence potato yields among adopters; hence, the differences in yield between users and non-users of CSP were examined. Table 6 presents the results of the analysis of differences in the sale of both ware and seed potato and incomes. It shows that there is a statistically significant difference in all the three outcome variables (i.e., yield, sales, and income) between users and non-users of CSP. Specifically, users of CSP produced more potato per hectare of land, and hence, sold more, thus earning more income from sales than their counterparts.

The results of analysis of the effect of using CSP on household food security (based on HFIAP) between users and non-users of CSP are presented in Fig. 2. The HFIAP is computed following [21] and is a snapshot measure of the degree of food insecurity in a household based on a 30 -day period. The figure shows that the higher proportion of non-users experienced food insecurity problems in the 30 days preceding this study. Specifically, more than $80 \%$ of non-users of CSP were either mildly or moderately food insecure as compared to about $59 \%$ of their counterparts. A Chi-square test of differences in the prevalence of food insecurity between users and nonusers of CSP yielded a $p$ value of 0.000 , indicating that the observed differences are indeed statistically significant. 
Table 3 Demographic and households' facility access statistics

\begin{tabular}{llll}
\hline Variables & $\begin{array}{l}\text { Users }^{\mathbf{a}}(\boldsymbol{n}=\mathbf{1 6 7}) \\
\text { Mean } \\
(\text { SD })\end{array}$ & $\begin{array}{l}\text { Non-users } \\
\text { Mean } \\
(\boldsymbol{S}=\mathbf{2 4 1})\end{array}$ & $\begin{array}{l}\text { Mean diff } \\
(\boldsymbol{t} \text { value })\end{array}$ \\
\hline distmkt & 27.31 & 32.7 & \\
& $(26.51)$ & $(29.24)$ & $-5.393^{*}$ \\
distroad & 28.42 & 28.82 & $(-1.937)$ \\
& $(27.85)$ & $(24.95)$ & -0.40 \\
distagric & 101.56 & 79.67 & $(-0.149)$ \\
& $(111.58)$ & $(81.28)$ & $21.891^{* *}$ \\
age & 49.08 & 48.49 & $(2.168)$ \\
& $(12.53)$ & $(13.89)$ & 0.59 \\
gender & 0.55 & 0.47 & $(0.45)$ \\
& $(0.5)$ & $(0.5)$ & 0.08 \\
education & 8.92 & 7.89 & $(1.63)$ \\
& $(3.86)$ & $(3.76)$ & $1.03^{* * *}$ \\
experience & 19.72 & 18.62 & $(2.69)$ \\
& $(12.41)$ & $(12.64)$ & 1.1 \\
phone & 0.96 & 0.89 & $(0.87)$ \\
& $(0.19)$ & $(0.32)$ & $0.08^{* * *}$ \\
hhdsize & 4.34 & 4.25 & $(3.05)$ \\
& $(1.59)$ & $(1.73)$ & 0.08 \\
depedency & & $(0.49)$ \\
& 15.30 & 11.29 & 4.01 \\
& $(46.76)$ & $(44.68)$ & $(0.86)$ \\
\hline
\end{tabular}

The numbers in parentheses are standard deviations (SD)

$*^{*}$ **, and ${ }^{* * *}$ significant at 10,5 , and $1 \%$, respectively

a Dependency ratio is calculated following the World Bank (2014) as the ratio of household members below 15 years or above 64 years of age to the working age members ( $15-64$ years)

Table 4 Household ownership of various farm assets, by farmer category

\begin{tabular}{|c|c|c|c|}
\hline \multirow[t]{2}{*}{ Variables } & \multirow{2}{*}{$\begin{array}{l}\text { Users }^{\mathrm{a}}(n=167) \\
\text { Mean } \\
\text { (SD) }\end{array}$} & \multirow{2}{*}{$\begin{array}{l}\text { Non-users } \\
(n=241) \\
\text { Mean } \\
(S D)\end{array}$} & \multirow[t]{2}{*}{$\begin{array}{l}\text { Mean diffa-b } \\
(t \text { value })\end{array}$} \\
\hline & & & \\
\hline Assets & $\begin{array}{l}1851 \\
(2645)\end{array}$ & $\begin{array}{l}738 \\
(1276)\end{array}$ & $\begin{array}{l}1113^{* * *} \\
(5.05)\end{array}$ \\
\hline livestock_asset & $\begin{array}{l}1783 \\
(1763)\end{array}$ & $\begin{array}{l}1239 \\
(1249)\end{array}$ & $\begin{array}{l}544^{* * *} \\
(3.47)\end{array}$ \\
\hline Land & $\begin{array}{l}2.00 \\
(1.79)\end{array}$ & $\begin{array}{l}1.00 \\
(0.75)\end{array}$ & $\begin{array}{l}1.00^{* * *} \\
(4.27)\end{array}$ \\
\hline cult_land & $\begin{array}{l}0.87 \\
(1.34)\end{array}$ & $\begin{array}{l}0.41 \\
(0.36)\end{array}$ & $\begin{array}{l}0.46^{* * *} \\
(4.24)\end{array}$ \\
\hline uncult_land & $\begin{array}{l}0.37 \\
(0.54)\end{array}$ & $\begin{array}{l}0.21 \\
(0.30)\end{array}$ & $\begin{array}{l}0.16^{* * *} \\
(3.45)\end{array}$ \\
\hline
\end{tabular}

The numbers in parentheses are standard deviations (SD)

${ }^{*},{ }^{*}$, and ${ }^{* * *}$ significant at 10,5 , and $1 \%$, respectively

The above section has demonstrated that there is some evidence that the use of CSP is associated with increases in the amount of pesticides used, potato yields,
Table 5 Test of differences in input use, in terms of ,value of inputs (USD), by users and non-users of CSP

\begin{tabular}{|c|c|c|c|}
\hline Variables & $\begin{array}{l}\text { Users }(n=167) \\
\text { A }\end{array}$ & $\begin{array}{l}\text { Non-users }(n=241) \\
\text { B }\end{array}$ & $\begin{array}{l}\text { Mean } \\
\text { diff }\end{array}$ \\
\hline Non-labor inputs & $\begin{array}{l}\text { Mean } \\
\text { (SD) }\end{array}$ & $\begin{array}{l}\text { Mean } \\
\text { (SD) }\end{array}$ & $\begin{array}{l}A-B \\
\text { ( } t \text { value })\end{array}$ \\
\hline seed_purchase & $\begin{array}{l}535 \\
(228.1)\end{array}$ & $\begin{array}{l}459.1 \\
(217.5)\end{array}$ & $\begin{array}{l}76.2^{* * *} \\
(4.10)\end{array}$ \\
\hline folier_feed & $\begin{array}{l}10.5 \\
(10.7)\end{array}$ & $\begin{array}{l}7.2 \\
(10.0)\end{array}$ & $\begin{array}{l}3.3^{* * *} \\
(3.20)\end{array}$ \\
\hline fertiliser & $\begin{array}{l}265.0 \\
(137.8)\end{array}$ & $\begin{array}{l}212.8 \\
(117.7)\end{array}$ & $\begin{array}{l}52.2^{* * *} \\
(4.10)\end{array}$ \\
\hline insecticide & $\begin{array}{l}9.7 \\
(10.1)\end{array}$ & $\begin{array}{l}5.8 \\
(8.4)\end{array}$ & $\begin{array}{l}3.9^{* * *} \\
(4.30)\end{array}$ \\
\hline fungicide & $\begin{array}{l}52.1 \\
(30.4)\end{array}$ & $\begin{array}{l}52.9 \\
(33.4)\end{array}$ & $\begin{array}{l}-0.8 \\
(0.25)\end{array}$ \\
\hline manure & $\begin{array}{l}91.2 \\
(107.0)\end{array}$ & $\begin{array}{l}81.0 \\
(94.5)\end{array}$ & $\begin{array}{l}10.2 \\
(1.02)\end{array}$ \\
\hline
\end{tabular}

$S D$ standard deviations

$*$, **, and ${ }^{* * *}$ significant at 10,5 , and $1 \%$, respectively

Table 6 Potato production, utilization and incomes, comparison between users and non-users of Kisima CSP

\begin{tabular}{|c|c|c|c|}
\hline \multirow[t]{2}{*}{ Variables } & \multirow{2}{*}{$\begin{array}{l}\text { Users }(n=167) \\
\text { Mean } \\
\text { (SD) }\end{array}$} & \multirow{2}{*}{$\begin{array}{l}\text { Non-users } \\
(n=241) \\
\text { Mean } \\
(S D)\end{array}$} & \multirow[t]{2}{*}{$\begin{array}{l}\text { Mean diff } \\
(t \text { value })\end{array}$} \\
\hline & & & \\
\hline yield (kg/ha) & $\begin{array}{l}11,584.8 \\
(6454.6)\end{array}$ & $\begin{array}{l}8787.1 \\
(5762.0)\end{array}$ & $\begin{array}{l}6994.3^{* * *} \\
(11.48)\end{array}$ \\
\hline $\begin{array}{l}\text { ware_potatosale } \\
\quad(\mathrm{kg})\end{array}$ & $\begin{array}{l}19,352.0 \\
(5188.2)\end{array}$ & $\begin{array}{l}5337.3 \\
(4596.2)\end{array}$ & $\begin{array}{l}14,014.7^{* * *} \\
(12.33)\end{array}$ \\
\hline $\begin{array}{l}\text { seed_potatosale } \\
\quad(\mathrm{kg})\end{array}$ & $\begin{array}{l}155.5 \\
(226.2)\end{array}$ & $\begin{array}{l}115.4 \\
(218.3)\end{array}$ & $\begin{array}{l}40.10^{* * *} \\
(4.50)\end{array}$ \\
\hline $\begin{array}{l}\text { income_potato } \\
(\mathrm{kg})\end{array}$ & $\begin{array}{l}1413.3 \\
(776.9)\end{array}$ & $\begin{array}{l}1054.8 \\
(804.0)\end{array}$ & $\begin{array}{l}10.21^{* * *} \\
(4.49)\end{array}$ \\
\hline
\end{tabular}

Standard deviations (SD) and $t$ values are in parentheses

$*$,**, and ${ }^{* * *}$ significant at 10,5 , and $1 \%$, respectively

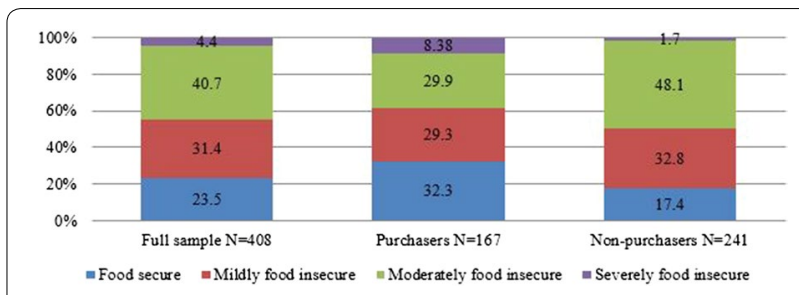

Fig. 2 Prevalence of food insecurity in the study households: results of HFIAP analysis, \% of responses. Chi-square $p$ value $=0.000$

and household food security status. Does this evidence persist under the use of the more rigorous econometric techniques? To address this question, we used propensity 
score matching (PSM) technique to test whether purchase of CSP increases pesticide use, potato yield, and household food security status.

The results of the Probit regression model, estimated as the first step of PSM estimation method, are shown in Table 7. They show that households located further from Kisima Farm are less likely to purchase CSP, probably due to the bulky nature of the seed and hence the high transport costs. On the other hand, a higher value of assets and land size owned prior to the purchase of CSP increase the likelihood of adopting CSP. The likelihood of purchasing CSP is also affected by membership to a farmer group, perhaps because such groups organize joint purchase to reduce transport and other transaction costs. The results further show a very strong effect of asset ownership on the likelihood of adopting CSP. This indicates that better off households are more likely to use CSP and could be related to the high cost of seed, and the accompanying costs of transporting seed from source to the farm.

Table 8 presents the measures of impact (i.e., the average treatment effect on the treated-ATT) of using CSP, computed using three matching approaches (algorithms) namely NNM, RM and KBM to check the robustness of the findings. Results show that the use of CSP has a statistically significant increase in potato yield. Specifically, on average, the use of CSP increases productivity by 2975 $9521 \mathrm{~kg}$ per hectare. Thus, these results corroborate

Table 7 Results of the probit regression model estimated to generate propensity scores for propensity score matching exercise

\begin{tabular}{lll}
\hline Variable & Coefficient & $\boldsymbol{p}$ value \\
\hline Explanatory variables & & \\
Inage & -0.326 & 0.245 \\
gender & 0.107 & 0.478 \\
occupation & -0.025 & 0.850 \\
education & 0.078 & 0.514 \\
hhdsize & -0.005 & 0.904 \\
Indistagric & 0.072 & 0.375 \\
Indistkisima & $-0.233^{* * *}$ & 0.004 \\
credit & -0.147 & 0.584 \\
Inland & $0.226^{* * *}$ & 0.000 \\
Inasset & $0.295^{* * *}$ & 0.000 \\
phone & 0.272 & 0.399 \\
groupmem & $1.404^{* * *}$ & 0.000 \\
constant & -2.786 & 0.032 \\
Model diagnostics & & \\
Observations & 408 & \\
Pseudo ${ }^{2}$ & 0.3005 & \\
$p$ value & 0.000 & \\
\hline
\end{tabular}

$*$,**, and ${ }^{* * *}$ significant at 10,5 , and $1 \%$, respectively those of descriptive analysis that showed that users of CSP had higher yields than their counterparts. Results also show that using CSP reduces household food insecurity. The HFIAP score, the measure of household food insecurity, fell between 2.2 and 2.5. The increase in yield and decline in food insecurity are consistent and statistically significant across all the three algorithms, indicating that these findings are robust. Table 8 further shows that the use of CSP increases the use of insecticides, albeit modestly, but has no significant effect on the quantity of fungicides applied. The value of insecticides used by purchasers of CSP increased by a modest amount of about USD 6/hectare.

In order to check the sensitivity of the results to the unobserved variables, the Rosenbaum (rbounds) tests were conducted (Table 9). The test sensitivity of the results relating to the value of fungicides used is not included, since Rosenbaum bounds (rbounds) are meaningful only for treatment effects that are significantly different from zero [15]. The levels of gamma in the three algorithms are slightly higher for the NNM on pesticide use and household food insecurity. These results imply, for example, for the NNM, that the odds of the unobserved covariates would have to increase by about twofold before they can negate the estimated impact. The results of the sensitivity analysis therefore indicate that the finding that use of CSP increases yield is very robust. They further suggest that no ordinary changes in the unobserved variables can change the results considerably.

\section{Summary conclusions and implications}

This study examined the effects of using CSP on farm households and on the use of yield-enhancing inputs with the potential to degrade the environment. Results of descriptive analysis indicate that use of CSP is associated with increased yields, sales, and hence income. In addition, users of CSP were less food insecure than their counterparts. These gains are, however, accompanied by a modest increase in the use of inputs, notably pesticides and fertilizer.

The results of the survey probit regression model estimated as the first step of implementing PSM indicated that farmer endowment with physical capital assets and group membership, distance to the source of CSP, and land ownership influence the likelihood of using CSP. Distance to source of CSP reduces the likelihood of its use, suggesting the significance of transaction costs in farmers' decision to use of CSP, but may also reflect the bulky nature of the seed potato.

The findings of the PSM estimation are in line with those of descriptive analysis. They confirm that users of CSP obtained higher yields, pesticide usage, and household food security. Users of CSP specifically used a 
Table 8 Results of propensity score matching analysis, for determining the effect of use of CSP

\begin{tabular}{|c|c|c|c|c|c|c|}
\hline \multirow{2}{*}{$\begin{array}{l}\text { Matching algorithm } \\
\text { Outcome variables }\end{array}$} & \multicolumn{2}{|c|}{ Nearest neighbor } & \multicolumn{2}{|l|}{ Radius } & \multicolumn{2}{|c|}{ Kernel-based } \\
\hline & ATT & $t$ stat & ATT & $t$ stat & ATT & $t$ stat \\
\hline fungicide & 13.6 & 0.78 & 8.2 & 0.99 & 8.16 & 0.97 \\
\hline insecticide & $6.6^{* *}$ & 2.36 & $6.2^{* *}$ & 2.78 & $6.53^{* *}$ & 2.83 \\
\hline yield & $9520.7^{* *}$ & 2.24 & $2975.4^{* *}$ & 2.12 & $3322.7^{* *}$ & 2.33 \\
\hline fertilizer & 234.5 & 0.99 & 31.2 & 1.02 & 43.0 & 1.40 \\
\hline foodsec & $-2.52^{* * *}$ & -3.25 & $-2.17^{* * *}$ & -2.86 & $-2.25^{* * *}$ & -3.90 \\
\hline
\end{tabular}

$*^{*},{ }^{*}$, and ${ }^{* * *}$ significant at 10,5 , and $1 \%$, respectively

Table 9 Results of sensitivity analysis for the hidden bias in the propensity score matching model

\begin{tabular}{lcrc}
\hline Outcome variable & Kernel-based & Radius & Nearest neighbor \\
\hline yield & $1.0-2.0$ & $1.0-2.0$ & $1.0-2.0$ \\
chemical & $1.3-1.4$ & $1.3-1.4$ & $1.5-1.6$ \\
foodsec & $1.8-1.9$ & $1.9-2.0$ & $2.0-2.1$ \\
\hline
\end{tabular}

slightly higher amount of insecticides than their counterparts. They also slightly increased their usage of fertilizers.

This study therefore concludes that the use of CSP has positive welfare effects on small farm households in terms of higher productivity (yield) and hence incomes. However, these gains can lead to increased use of pesticides as farmers defend their investment in certified seed. This study therefore concludes that the use of CSP has positive welfare effects on small farm households in terms of higher productivity (yield) and hence incomes. However, these gains can lead to increased use of pesticides as farmers defend their investment in certified seed. The findings of this study have at least three implications. First, they imply that use of certified seed indeed has welfare benefits to smallholder households. Such benefits are in the form of increased productivity and, subsequently, increased income for those that participate in the market through sales. Hence, the findings imply the need to promote farmer use of quality/clean seed. Second, the finding that the use of certified seed could encourage the use of pesticides implies the need to train farmers on the safe use of pesticides in order to avoid potential negative effects exposure to such chemicals. Third, the strong correlation between asset ownership and access to CSP implies that access by poorer smallholder farmers may be constrained. This can, however, be overcome by organizing such farmers together as a group and sourcing seed jointly, thus enabling them to reduce per unit costs and benefiting through economies (due to discounts or lower per unit transportation costs).
This study has a few limitations. First, the study was conducted among a relatively small sample of potato growers and targeted only one region of Kenya, the Mt Kenya region. Thus, the findings are rather context specific. Future studies need to examine the effect of use of certified seed among a larger sample and in a broader context. Second, the study was conducted during a year that had fewer rains than usual. It is expected that the poor rains resulted in poor yields that would have been attained during normal year. Thus, the productivity and sales estimates presented in this study may have underestimated the actual performance under normal weather.

\section{Abbreviations}

ATT: average treatment effect on the treated; CSP: certified seed potato; HFIAP household food insecurity access prevalence; KBM: kernel-based matching; KFL: Kisima Farm Ltd; NNM: nearest neighbor matching; PSM: propensity score matching; RM: radius matching; USD: United States dollar; "3G": 3-generation; a rapid potato seed multiplication technique.

\section{Authors' contributions}

$J J O$ is the lead writer. He drafted the paper and jointly with other authors has revised the original draft to the submitted manuscript. YZ has closely contributed to the paper in improving the papers' structure, methodology, and other contents through several rounds of reviews and revisions. NK contributed to the analysis of the data and estimation of regression models in the paper as well as revision of the text. SOO contributed to the survey design and collection of the data and data analysis as well as the earliest estimated regression models. IB and ES contributed to the study design and the revision of the drafts of this manuscript. EA and JTA contributed to the survey design, generation of sampling frame, sampling and the collection of data used in this manuscript. All authors read and approved the final manuscript.

\section{Author details}

${ }^{1}$ International Potato Center, Sub Sahara Africa Regional Office, Nairobi, Kenya. ${ }^{2}$ Syngenta Foundation for Sustainable Agriculture, Basel, Switzerland. ${ }^{3}$ Department of Agricultural Economics and Rural Development, GeorgAugust-University Goettingen, Göttingen, Germany. ${ }^{4}$ Global Chemicals and Agriculture Practice, North American Knowledge Center, McKinsey \& Company, Waltham, MA, USA.

\section{Acknowledgements}

We acknowledge funding for this study from Sygenta Foundation for Sustainable Agriculture; International Potato Center; and the Roots, Tubers and Bananas CGIAR Research Program. We also acknowledge the support of a large team of staff who collected the data used in this manuscript. 


\section{Competing interests}

The authors declare that they have no competing interests in this study and that it was conducted solely for the purpose of learning and knowledge.

\section{Availability of supporting data}

Supporting data can be made available upon request to the lead author via the provided contact information.

\section{Consent for publication}

The consent to publish this paper is granted by all the authors. All authors read and approved the final manuscript.

\section{Ethical approval and consent to participate}

This study did not involve collection of blood samples or health information. Hence, no ethical approval was needed. However, farmer consent to participate in the study was obtained through verbal agreement upon presentation of a written consent statement that specified that participation in the study was voluntary, that the participant could withdraw anytime and choose not to answer some questions, and that refusal to participate had no penalty or any kind. Consent to the study was sought before proceeding with the interviews.

\section{Funding}

This research was funded by Sygenta Foundation for Sustainable Agriculture; International Potato Center; and the Roots, Tubers and Bananas CGIAR Research Program (RTB CRP).

Received: 6 August 2016 Accepted: 24 February 2017

Published online: 08 March 2017

\section{References}

1. Shaaban H, Kisetu E. Response of irish potato to NPK fertilizer application and its economic return when grown on an Ultisol of Morogoro, Tanzania. J Agric Crop Res. 2014;2(9):188-96.

2. Muthoni J, Nyamongo DOA. Review of constraints to ware irish potatoes production in Kenya. J Hortic For. 2009:1(7):98-102.

3. Obare GA, Nguyo DONW, Mwakubo SM. Are Kenyan smallholders allocatively efficient? Evidence from Irish potato producers in Nyandarua North district. J Dev Agric Econ. 2010;2(3):078-85.

4. Muthoni JJ, Shimelis H, Melis R. Potato production in Kenya: farming systems and production constraints. J Agric Sci. 2013;5(5):p182.

5. Kaguongo WP, Gildemacher P, Demo P, Wagoire W, Kinyae P, Andrade J, Thiele G. Farmer practices and adoption of improved potato varieties in Kenya and Uganda. Soc sci working pap. 2008;5:78-85

6. Laibuni NM, Omiti JM. Market structure and price: An empirical analysis of irish potato markets in Kenya. https://scholar.google.com/scholar?hl= en\&q=Laibuni+and+Omiti+2014\&btnG=\&as_sdt=1\%2C5\&as_sdtp=. Accessed 30 June 2016.
7. Were HK, Kabira J, Kinyua ZM, Olubayo FM, Imbuaga B, Abshir A, Torrance L. Potato production challenges in Kenya. Int J Appl Agric Res 2013;8(2):133-146.

8. Barrett CB. Smallholder market participation: concepts and evidence from eastern and southern Africa. Food Policy. 2008;33(4):299-317.

9. Ogutu SO, Okello JJ, Jakinda DO. Impact of information and communication based market information services on smallholder farm input use and productivity: the case of Kenya. World Dev. 2014;64:311-21.

10. Obado J. 3G Baseline Report, Kenya in the USAID funded project: tackling the food price crisis in Eastern and Central Africa with the humble potato: enhanced productivity and uptake through the $3 \mathrm{G}$ revolution. March 2010, unpublished.

11. Ali A, Abdulai A. The adoption of genetically modified cotton and poverty reduction in Pakistan. J Agric Econ. 2010;61(1):175-92.

12. Ali A, Abdulai A, Goetz R. Impacts of tenancy arrangements on investment and efficiency: evidence from Pakistan. Agric Econ. 2012;43(s1):85-97.

13. Becerril J, Abdulai A. The impact of improved maize varieties on poverty in Mexico: a propensity score-matching approach. World Dev. 2010;38(7):1024-35.

14. Dehejia RH, Wehba S. Propensity score-matching methods for nonexperimental causal studies. Rev Econ Stat. 2002:84(1):151-61.

15. Caliendo M, Kopeinig S. Some practical guidance for the implementation of propensity score matching. J Econ Surv. 2008;22(1):31-72.

16. Wafula L, Oduol J, Oluoch-Kosura W, Muriuki J, Okello J, Mowo J. Does strengthening technical capacity of smallholder farmers enhance adoption of conservation practices? The case of conservation agriculture with trees in Kenya. Agrofor Syst. 2015;90(6):1045-1059.

17. Vanlauwe B, Wendt J, Giller KE, Corbeels M, Gerard B, Nolte C. A fourth principle is required to define Conservation Agriculture in sub-Saharan Africa: the appropriate use of fertilizer to enhance crop productivity. Field Crops Res. 2014;155:10-3.

18. Larson DF, Savastano S, Murray S, Palacios-López A. On the determinants of low productivity in maize farming in Uganda: The role of markets, fertilizer use and gender. In: Otsuka K, Larson DF, editors. In pursuit of an African green revolution. Tokyo: Springer; 2016. p. 165-82.

19. Kimwaga RJ, Mashauri DA, Bukirwa F, Banadda N, Wali UG, Nhapi I. Development of best management practices for controlling the non-point sources of pollution around Lake Victoria using SWAT Model: a Case of Simiyu catchment Tanzania. Open Environ Eng J. 2012;5:77-83.

20. Cheng ZH, Luo F. Assessment of economic losses on agricultural nonpoint source pollution by abuse of fertilizer in Manasi River Basin of China. Adv Mater Res. 1073;2015:484-8.

21. Swindale A, Bilinsky P. Household food insecurity access scale (HFIAS) for measurement of household food access: indicator guide (v. 3). Washington, DC: Food and Nutrition Technical Assistance Project, Academy for Educational Development; 2007.

\section{Submit your next manuscript to BioMed Central and we will help you at every step:}

- We accept pre-submission inquiries

- Our selector tool helps you to find the most relevant journal

- We provide round the clock customer support

- Convenient online submission

- Thorough peer review

- Inclusion in PubMed and all major indexing services

- Maximum visibility for your research

Submit your manuscript at

www.biomedcentral.com/submit 